\title{
Developing Learning-Based Problem-Based Learning to Improve Problem Solving of Students in Grade VIII
}

\author{
Suci Permata Syafermi \\ Department of Mathematics \\ State University of Padang \\ Padang, Indonesia \\ sucisyafermi@gmail.com
}

\author{
Yerizon \\ Department of Mathematics \\ State University of Padang \\ Padang, Indonesia \\ yerizon@yahoo.com
}

\author{
Budhi Oktavian \\ Department of Chemistry \\ State University of Padang \\ Padang, Indonesia
}

\begin{abstract}
This research aims to develop Problem based learning media to improve the mathematical problemsolving abilities of students. The Learning media developed in this research in the form of RPP and LKPD. This research used to research and development (R \& D) method by following Plomp Model which begin with the preliminary research phase, development phase, and assessment phase. Need analysis, curriculum analysis, students analysis related to the problems in learning were done in the preliminary phase. In the development or prototype making is done Lesson Plane Design and LKPD of Problem based learning, then selfevaluation was conducted. Which discussed with the supervisor Mathematics learning media is them validated by five experts where three experts from the mathematics field, one from Education technology and one form linguist until the learning media is said valid and can be tasted. The subject of this research is eighthgrade students of SMPN 2 Pariaman where three students in one to one, eight students in a small group, and twenty-seven students in the field test. In the assessment phase, practical and effective tests were done limitedly. The practicality data is obtained from the implementation sheet of lesson plans, a questionnaire of teacher and students. The Effectiveness data is obtained from the students' learning result in the form of the final test to see students' problem-solving abilities. The result of the research will produce a valid, practical and effective mathematics learning media to improve Eighthgrade students' problem-solving abilities.
\end{abstract}

Keywords - Problem-based Learning, Problem Solving, Plomp Model.

\section{INTRODUCTION}

Mathematics is one of the many knowledge that is utilized in everyday life, both in general and in particular. In general, mathematics is used in trade transactions, carpentry, and others. In almost every aspect of the life of mathematics that is applied, therefore mathematics gets the nickname as the queen of all sciences. Based on this statement, mathematics is one of the compulsory lessons that exist in every level of education at school. Mathematics learning according to Bruner (Herman Hudoyo, 1998: 56) is learning about the concepts and structures of mathematics contained in the material studied and looking for the relationship between the concepts and mathematical structures in them. [1].

The National Council of Teachers of Mathematics (NCTM) in 2000 stated that the five mathematical abilities that students should possess are (1) learning to communicate (mathematical communication); (2) learning to reason (mathematical reasoning); (3) learning to solve problems (mathematical problem solving); (4) learning to associate ideas (mathematical connection); (5) learning to represent ideas (mathematical representation). [2]

Mathematics learning carried out in schools today generally still does not provide opportunities for students to develop their problem-solving abilities, while problemsolving is one of the important elements as the process of finding the best way to remove obstacles faced to achieve a specific goal in accordance with the opinion of Memnun (2012) "Problem-solving, which is one of the important elements of school mathematics, can be defined as the process of finding the best way to clear the difficulties that are faced in order to achieve a certain objective ". [3]

Based on observations at SMPN 1 Pariaman and SMPN 2 Pariaman, the learning process was still centered on the teacher. The teacher presents the material to students and students listen to the explanation from the teacher. The response of students in learning is quite good, seen from the interaction between teachers and students. Based on interviews with researchers with mathematics teachers, students have been given problem-solving problems but the questions given are limited to the questions that are in the textbook only. So, students are less skilled at solving various problems with the problem-solving ability. In addition, some schools use other teaching materials such as LKPD, but of course, the LKPD that is designed must be in line with the expected learning objectives and can improve students' mathematical problem-solving skills.

Based on the problems that have been stated above, it is necessary to develop a mathematics learning tool for 
grade VIII SMP which can improve students' mathematical problem-solving skills. Therefore, in this study, a problembased learning tool (PBL) was designed to improve the problem-solving ability of students in the eighth grade of junior high school. PBL or problem-based learning as a learning model that uses real-world problems as a context for students to learn about critical thinking and problemsolving skills, and to acquire essential knowledge and concepts from the subject matter. This is also consistent with the opinion of Ari (2014) which states that "While PBL scenarios are necessary to speak about the characteristics, it is a problem that is difficult and time consuming for teachers after student teachers are expressed that these problems can help to raise students as real problem solvers in their future lives by writing about these problems with their experiences outside the school and how to attract their attention. [4]

PBL begins with problems that in this case can be raised by students or teachers, then students deepen their knowledge about what they already know and what they need to know to solve the problem. This is also consistent with Crowley (2015) who stated that "there are two cognitive hypotheses as to why PBL is effective - the activation-elaboration hypothesis and the situational interest hypothesis. In the activation-elaboration hypothesis, PBL serves to activate prior knowledge and identify gaps in what students already know. Once this has been accomplished, students can then elaborate on this already-developed knowledge with new knowledge ". [5]. Students can choose problems that are considered interesting to solve so they are motivated to play an active role in learning.

In learning there needs to be a learning resource, so to support the learning process PBL-based RPP and LKPD are needed which will be directed to the problem solving process, the Toolkit will contain PBL procedures, which will increase students' understanding of the concepts learned, so that it will help and facilitate students in solving the mathematics problems they learn.

The formulation of the problem in this study is "How are the characteristics of problem-based mathematics learning tools for students in class VIII SMP valid, practical and effective to improve students' problem-solving abilities?". The purpose of this study was to produce a PBLbased mathematics learning tool to improve the problemsolving skills of students in grade VIII SMP which are valid, practical, and effective. In addition, this research is expected to be useful for teachers and students as additional learning tools that can be used in mathematics learning in schools. The results of this study in the form of RPP are designed by applying problem-based learning and LKPD which is designed also related to problem-based learning. The RPP and LKPD developed are limited to the Pythagoras Theorem in the even eighth grade of SMP / MTs.

This PBL allows each student to build their own designs about the problems they face. This PBL model introduces students to a problem that is relevant to the teaching material. The problem will be solved through a series of activities such as finding/identifying problems, gathering facts, formulating hypotheses, conducting investigations, and concluding alternative solutions to problems. These activities will help students to work to solve problems in a systematic way to achieve mastery of mathematical abilities, especially the ability to solve problems in students. According to Suprihatiningrum (2012: 215), Problem Based Learning (PBL) is a learning model in which students are faced with a problem from the beginning, then followed by an information search process that is student-centered. [6]

The learning implementation plan (RPP) is a learning plan that is developed in detail referring to the syllabus, lesson textbooks, and teacher's guidebook. While the student worksheet (LKPD) is one type of teaching material that helps students in the learning process. LKPD contains steps for activities that must be carried out by students to find concepts of learning and exercises.

Student worksheets (LKPD) is one of the means to help and facilitate teaching and learning activities so that effective interaction between students and educators will be formed, which in turn can increase students' activities in improving learning achievement. Widjajanti (2008: 1) said that "LKPD is one of the learning resources that can be developed by educators as facilitators in learning activities". [7] The prepared LKPD can be designed and developed according to the conditions and situations of learning activities that will be faced. So that LKPD is important as a supporting tool in the learning process.

\section{METHODS}

This type of research is a development research using the Plomp model, which consists of three phases, namely the initial investigation phase (preliminary research), the development or prototyping phase, and the assessment phase. The initial investigation phase (preliminary research) consists of needs analysis, curriculum analysis, concept analysis and student analysis. In the prototyping phase, this prototype was made the formative evaluation. The development phase or prototyping phase consists of prototype 1 , namely self-evaluation; prototype 2 , one to one; prototype 3 , small group; prototype 4 , namely the field test, in the assessment phase (assessment phase), a field test was conducted in class VIII of SMP 2 Pariaman to see the practicality and effectiveness. Research data was collected through self-evaluation sheets, validation sheets, observation sheets and interview guidelines, teacher and student response questionnaire sheets, RPP implementation observation sheets, final sheets and learning outcomes. Validation of learning devices was carried out by five lecturers consisting of three Mathematics lecturers, one Indonesian lecturer, and one Education Technology Lecturer.

\section{RESUlTS AND DISCUSSION}

The following is described the results obtained based on the research that has been carried out along with the implementation process.

A. Initial Investigation Phase

The initial investigation phase was carried out with the aim of knowing the form and characteristics of the learning device to be developed. This phase carried out several activities including needs analysis, curriculum analysis, concept analysis and analysis of students.

Based on the needs analysis, information was obtained that the teacher had used the lesson plan based on the 2013 curriculum, but the strategy used still did not 
facilitate students to be active when studying in school. In addition, the teacher does not have teaching materials that facilitate students in honing problem-solving skills.

Based on the analysis of the curriculum, it was carried out in two aspects, namely Core Competence (KI) and Basic competency (KD) for the eighth-grade junior high school material. KI and KD refer to the 2013 curriculum provisions, while indicators of achievement of competencies, researchers adjust to the RPP that researchers develop. The material taken for the development of the device in this study is the Pythagoras Theorem material.

In concept analysis, activities are carried out to identify, detail, and systematically compile the main materials that students will learn. The material arranged systematically. The material that will be used in this research is Pythagoras's Theorem material. The subject matter includes: Rediscovering the Pythagorean theorem, Calculating the length of a side of a right triangle if the other two sides are known, Determining the type of triangle based on side lengths, and Pythagorean triples, Calculating the proportions of right-angled triangles with one angle $30^{\circ}, 45$ ${ }^{\circ}$, and $60^{\circ}$, resolving the real problems associated with the Pythagoras theorem.

Based on the analysis of students, it can be concluded that students have difficulty receiving lessons taught by teachers in school, this is because students are not ready to learn in class. Based on interviews with students, students want interesting and not boring learning resources.

B. Prototype Development Phase

1. Designing Learning Devices

Preliminary Research results are used as a basis for developing or making prototypes. After the indicators are formulated, and the concept map is determined, the next step is to design learning tools in the form of RPP and LKPD. The following will describe the characteristics of RPP and LKPD based on the problem to be designed.

a. Characteristics of RPP

Learning Implementation Plans (RPP) are guidelines for teachers in implementing learning. The RPP is prepared for each KD that can be held in one meeting or more. The teacher designs a lesson plan for each meeting that is adjusted to scheduling in the education unit.

Learning activities consist of three stages: introduction, core, and closing. In these three activities, there are steps based on problem-based learning. The preliminary activity is a stage to convey learning and motivating goals that function to generate motivation and focus students' attention to actively participate in the learning process and create a responsive learning atmosphere. The learning activities in the lesson plan begin with the teacher conveying the objectives. Then the teacher asks the students to answer the questions or questions contained in the LKPD with their group friends and discuss the answers.

A good LKPD is an LKPD that can be used according to the ability of students. The ability of different students makes it possible to study with a group discussion system. Learning with a group system that is heterogeneous, will make students with low ability to learn with group members who have high abilities. Therefore, it is necessary to choose the right group discussion model so that all group members can play an active role in group discussions.

\section{b. Characteristics of LKPD}

LKPD is developed according to core competencies, basic competencies, indicators and learning objectives. The presentation of the material in the LKPD begins with a preliminary activity that is able to express learners' understanding of the material presented in the LKPD, in addition, students are also directed to add things related to the material learned at the time, but not explained to LKPD. The aim is so that participants can contribute more and are active in learning activities. Learners find their own material and understand it. The role of the teacher here is to guide the course of the discussion, answer the questions of students, and provide confirmation or reinforcement of students' understanding of the material.

Group discussion activities end with group presentations that can represent the students' understanding of the material and set forth in the completion of several sample questions. The teacher manages the course of the discussion to fit the set time, which is 45 minutes. After the group discussion is over, students are asked to answer independent practice questions. This issue is given with the aim that students are able to understand their own potential by answering questions without the help of others. This can also be a benchmark for teachers at each meeting of the learning process.

\section{Prototype 1 and 2}

Prototype 1 is the initial stage of the results of the learning device design. To obtain a valid device, there are two steps taken to validate the learning device, namely selfevaluation and expert review.

a. Self Evaluation Results (Prototype 1)

This activity was carried out by the researchers themselves before being assessed by experts, with the aim of investigating errors that occurred in the design of prototype learning devices 1 . Self-evaluation was carried out by rereading the RPP draft, reading and evaluating the LKPD. The self-evaluation of learning tools was carried out with the aim to see if there were still errors made when making prototype 1 on the learning device. The things that are considered in the evaluation itself are typing errors, writing clarity, picture clarity, misuse of terms, misuse of punctuation, completeness of components in RPP and LKPD.

After the evaluation itself, several errors were found in the prototype 1 RPP and LKPD. The error was then corrected by the researcher. Such errors are like, In RPP there are some typing errors, the use of punctuation. In LKPD, there are several typing errors, misuse of punctuation marks, columns for filling in problems are too small.

\section{b. Learning Device Validation Results By Expert} Review (Expert Review) Prototype 1 learning devices that have been designed and evaluated by themselves are validated. Validation of learning devices is carried out by experts/experts in their respective fields. Before being validated by experts/experts in their respective fields, first, this prototype 1 learning device that has been evaluated and revised, was consulted to the two researchers. Based on the results of guidance by Supervisors I and II, several suggestions for improvements to the prototype 1 learning device were obtained. The following is a description of 
suggestions for improvements and the results of improvements to prototype 1: First, adjust the PBL steps in the core activities. Second, the questions in the LKPD are made to direct students to construct their knowledge of the material being studied

After guiding and repairing prototype 1 learning devices, the next activity is to validate the product. Validation is carried out by five experts, consisting of 3 mathematical education experts, one language expert, and one educational technology expert. The list of validator names can be seen in Appendix 1. The focus of this activity is on the content validity and construct validity of the prototype 1 learning device. So in general, the assessment is done in terms of content, language, and display of the prototype 1 learning device. The following is a description of the RPP and LKPD validation results.

a) RPP validation results

The RPP validation was carried out by the five validators, during the validation phase some suggestions were made for the improvement of the RPP. Revisions made are in accordance with the advice of the validator. The suggestion from the validator for the RPP 1 prototype is, (1) Adjust the Competency Achievement Indicator with the subject matter, (2) Pay attention to the use of the sentence according to Indonesian Spelling (EBI), (3) Improve the use of imprecise punctuation.

After revising based on the advice of the validator, the results of the improvement are shown again to each validator and given a quantitative assessment. Overall RPP developed is said to be valid with an average of 0.926 . So, it can be concluded that this RPP has been valid. The results of the problem-based RPP validation data analysis in Appendix 10. Prototype 1 RPP that has been valid is then named Prototype 2 RPP.

b) Results of LKPD validation

To obtain a valid LKPD and in accordance with the expected objectives, Prototype 1 LKPD is validated by five experts who will advise and assess the LKPD according to the expertise of each expert or validator. The validator consists of three Mathematics Education lecturers, one Language lecturer, and one educational technology lecturer. Based on the consultations conducted at each validator, several suggestions for improvement on LKPD were obtained. Revisions to LKPD are carried out in accordance with the advice of the validator. Suggestions from the validator for LKPD are (1) improvement of the problems that exist in LKPD (2) Pay attention to the composition of colors, font sizes and images that are not porous in the LKPD cover, (3) Improve the use of non-standard sentences and use of punctuation that is not appropriate so not ambiguous when students understand it.

After revising based on the advice of the validator, the results of the improvement are shown again to each validator and given a quantitative assessment. Overall the developed LKPD is said to be valid with an average of 0.8807. So, it can be concluded that LKPD based on this problem is valid. The results of the problem-based LKPD validation data analysis are seen in Appendix 19. The valid prototype 1 LKPD is then named Prototype 2 LKPD.

c. One-One Evaluation (One To One Evaluation)

One-on-one evaluation of Prototype 2 learning devices carried out at the research trial school, namely at
SMP 2 Pariaman. Students who are the subject of one LKPD evaluation consist of three people with different abilities, namely high, medium and low abilities. LKPD one-on-one evaluations are carried out with the aim of identifying possible errors such as grammar that is not understood by the participants, unclear instructions, ease of use, attractiveness, and satisfaction. One-on-one evaluations are held 6 times.

One-on-one evaluations are carried out by asking students to understand and work on the activities contained in the LKPD. Although the LKPD activities must be carried out in groups, in the evaluation one by one the students are asked to work individually. During the one-on-one evaluation, researchers monitor and convey to students about the obstacles encountered while working on LKPD activities at each meeting. These constraints become a record for researchers for improvement materials. Then after completion, interviews were conducted with each student about the LKPD. After improvements to LKPD were carried out based on the one-on-one evaluation, Prototype 2 learning tools were evaluated by carrying out learning in small groups of students or small group evaluations.

\section{d. Small Group Evaluation}

The prototype 2 learning device was tested in a small group of 8 students of class VIII.2 of SMP 2 Pariaman. The purpose of small group evaluation is to identify the lack of learning tools. Small group evaluation is carried out by carrying out real learning, only with limited students.

After the learning process, all meetings are finished, then the researcher conducts interviews with students to see the practicality of the learning device. From the results of the interview, it was found that the average student with high, medium and low ability was able to understand the LKPD provided.

e. Field Test

Prototype 4 LKPD was then tested in large groups, namely one class of students in class VIII.3 of SMP 2 Pariaman. Whereas, the prototype 4 RPP was tried by the 8th-grade junior high school mathematics teacher. The subjects of the trial prototype 4 learning device were students of class VIII.3 of SMP 2 Pariaman and the mathematics teacher who taught in the class. While researchers act as observers. The trial was carried out to evaluate the practicality/use of RPP and LKPD used in problem-based learning. Evaluation is carried out in 5 meetings. Before using RPP, the researcher explained to the teacher about the steps of problem-based learning implemented. In addition, the teacher also gives the opportunity to researchers to explain the research activities in the class of trials

\section{Assessment Phase (Assessment Phase)}

The assessment phase is carried out after the learning tool is tested at the field test stage carried out on students of class VIII.3 of SMP 2 Pariaman. Assessment is carried out to assess the practicality and effectiveness of learning devices. The practicality of the learning tool is assessed by giving a practicality questionnaire to the teacher and students who have carried out the learning with the device. While effectiveness is assessed by giving a test to see the learning outcomes of students. The effectiveness aspect observed in this learning is the students' 
mathematical problem-solving ability. The students' answers were assessed with a rubric of scoring mathematical problem-solving abilities. The giving of questionnaires and tests to students for assessment is carried out after completing learning at the field test stage.

1. The practicality of Learning Tools

a. The practicality of Learning Tools by Teachers

Based on interviews with teachers after the learning was carried out in the field test activities, the teacher said that the RPP could be carried out easily because the steps contained in the RPP were very detailed. Based on the interview, the teacher also said that the questions on the LKPD were very helpful and in accordance with the material that the KD wanted to achieve. The LKPD can guide students to construct knowledge with teacher guidance.

From the observation results, the practical value of RPP by the teacher is $87 \%$ which is in very practical criteria. From the data obtained, both through questionnaires and observations obtained the same results, namely learning tools especially RPP have been practical. So it can be concluded that the learning activities in the lesson plan can be implemented properly by the teacher in learning.

b. LKPD Practices by Students

Based on the questionnaire filled by the students after the learning was carried out in the field test activities, the practical value of LKPD was $84.4 \%$ which was in very practical criteria. So, it can be concluded that the learning activities in LKPD have been carried out well by students.

\section{c. Learning Device Effectiveness}

The effectiveness of the use of problem-based mathematics learning devices that have been developed is seen by conducting tests to determine students' mathematical problem-solving abilities. The instrument used was an essay test. Based on the test results that have been carried out by scoring students 'mathematical problemsolving abilities, the average value of mathematical problem-solving ability of students is 88 . Based on the test results, it can be seen that the students' scores are above the $\mathrm{KKM}$, and the percentage of students whom complete exceeds $75 \%$, means that the product can be said to be effective. In addition, when viewed from the first meeting when testing the product in class, it was seen that the number of students who answered the independent practice questions correctly increased up to the fourth meeting, and the mistakes of students in answering the questions referred to the indicators of mathematical connection ability reduced each meeting. This means that students' mathematical problem-solving abilities increase.

\section{CONCLUSIONS AND RECOMMENDATIONS}

Based on the development process that has been carried out, the results are in the form of problem-based mathematics learning tools for the even semester Phytagoras Theorem material in the form of valid, practical and effective RPP and LKPD.

Based on the research that has been carried out, it can be suggested that problem-based mathematics learning devices for even Phytagoras theorem material in the form of RPP and LKPD that have been developed are valid, practical and effective can be used in mathematics learning in schools and it is expected that there are further trials in other schools to see the practicalities and broader effects of the learning tools developed.

\section{REFERENCES}

[1] Hudoyono. Herman, Mengajar Belajar Matematika, Jakarta: Depdikbud, 1998.

[2] NCTM, Principle and Standard for School Mathematics, Reston, VA: NCTM, 2000.

[3] Memnun, Dilek Sezgin., Hart, Lynn. C \& Akkaya, Recai, A Research on the Mathematical Problem Solving Belief of Mathematics, Science and Elementary Pre-Service Teachers in Turkey in terms of Different variables, International Journal of Humanities and Social, 2012.

[4] Ari, A. Azru., Katranci. Yasemin, The Opinions of Primary Mathematics Students-teachers on Problem based Learning Method, ScienceDirect, 2014.

[5] Crowley, B. Marie, The effect of Problem-Based Learning on Mathematics Achievement of Elementary Students across Time, TopSCHOLAR, 2015.

[6] Suprihatinigrum, Strategi Pembelajaran Teori dan Aplikasi, Yogjakarta: AZ-RUZZ MEDIA, 2012.

[7] W. Endang, Kualitas Lembar Kerja Siswa. (Online), (staff.uny.ac.id/system/files/pengabdian/endang.../kualitas-lks.pdf, accessed 24 November 2016), 2008. 